Open Access

\title{
Using inquiry-based writing instruction to develop students' academic writing skills
}

Bantalem Derseh Wale ${ }^{*}$ and Yenus Nurie Bogale

\author{
* Correspondence: bantalemd@ \\ gmail.com \\ Department of English Language \\ and Literature, Faculty of Social \\ Sciences and Humanities, Woldia \\ University, Woldia, Ethiopia
}

\begin{abstract}
The aim of this study was to investigate the effects of using inquiry-based writing instruction on students' academic writing skills. A pretest-posttest two groups quasiexperimental design was employed. Data were obtained through test, focus group discussion, and reflective journal from 62 first-year pharmacy students who were selected using comprehensive sampling. While the experimental group received the inquiry-based writing instruction, the control group learned using the conventional learning method. The quantitative data were analyzed using independent samples Ttest and descriptive statistics when the qualitative data were analyzed thematically. The findings revealed that there was a statistical difference between the control and experimental groups in their academic writing performance. Hence, students who participated in the inquiry-based writing instruction improved their academic writing skills. Mainly, students who learned through inquiry-based writing instruction were able to produce essays that addressed task achievement, coherence and cohesion, lexical resource, grammatical range and accuracy. Thus, this study recommends researchers, teachers, and students to pay due attention to inquiry-based writing instruction in their academic journey.
\end{abstract}

Keywords: Academic writing, Inquiry-based, Pharmacy students, Writing instruction

\section{Introduction}

Inquiry-based writing instruction is a form of gaining knowledge and skills through asking for information. It is a discovery method of learning which starts learning by posing questions, problems or situations rather than presenting facts directly to students. It involves students in making observations; posing questions; examining sources; gathering, analyzing, interpreting, and synthesizing data; proposing answers; explanations and predictions; communicating findings through discussion and reflection; applying findings to the real situation, and following up new questions that may arise in the process. In the process of inquiry-based learning, students identify and research issues with teacher support to develop their knowledge, and the teacher facilitates the learning process (Sandoval, 2005; Hardin, 2009 \& Marshall, 2013).

Inquiry-based writing instruction is a language learning methods under the umbrella of Communicative Language Teaching (CLT) that drives learning through inquisition and investigation. Lee (2014) stated that inquiry-based learning is an advanced version

(c) The Author(s). 2021 Open Access This article is licensed under a Creative Commons Attribution 4.0 International License, which permits use, sharing, adaptation, distribution and reproduction in any medium or format, as long as you give appropriate credit to the original author(s) and the source, provide a link to the Creative Commons licence, and indicate if changes were made. The images or other third party material in this article are included in the article's Creative Commons licence, unless indicated otherwise in a credit line to the material. If material is not included in the article's Creative Commons licence and your intended use is not permitted by statutory regulation or exceeds the permitted use, you will need to obtain permission directly from the copyright holder. To view a copy of this licence, visit http://creativecommons.org/licenses/by/4.0/. 
of Communicative Language Teaching (CLT), and it is an expansion of task-based instruction. It is an analogy for communicative approach that stresses discovery method using thoughtful questions to achieve learner cognitive development. The principles of inquiry-based writing instruction are compatible with CLT because the communicative approach focuses on communicative proficiency rather than mere mastery of structure to develop learners' communicative competence as to inquiry-based instruction. Inquiry-based writing instruction is, therefore, a form of Communicative Language Teaching which serves to bring down the general principles of communicative approach, and implement in language classrooms in an inquisitive and discovery manner (Lee, 2014; Qing \& Jin 2007; Richards \& Rodgers, 2001).

Inquiry-based writing instruction is helpful for the improvement of English language learning in general and academic writing skills in particular since the method follows a discovery approach that students themselves discover knowledge. Particularly, inquirybased writing instruction helps students get engaged in prewriting tasks through generating ideas, discovering and clarifying a writing topic, exploring information on their writing topics from various sources, explaining their discoveries or concepts gained from the exploration, and elaborate their thinking through transforming their understanding into their real world situation (Marshall, 2013; Wale, \& Bishaw, 2020). When students come up through this distinct writing process in manipulating such writing tasks, their ability to analyze, synthesize, and evaluate issues can be empowered because this process can develop students' academic writing skills.

The present study also showed that pharmacy students' academic writing skills have been developed through using inquiry-based writing instruction because the method focuses on the process of knowledge discovery that involves students in self-inquisition. The study can contribute a lot to the field of English language learning by possibly leading teachers and learners into a discovery learning method. Consequently, the study has applicable significances to academic writing teachers to understand the nature and application of inquiry-based academic writing instruction.

\section{Literature review}

\section{The implementation of inquiry-based writing instruction in academic writing}

The implementation of inquiry-based writing instruction incorporates engagement, exploration, explanation, elaborate, assessment and reflection (Marshall, 2013). In this learning model, Assessment and Reflection are regarded as integrated elements to be implemented in each of the following four phase. In other terms, students evaluate their performance and way of learning at each of the four steps, and reflect it to their colleagues, teachers, experts, and parents.

The first stage of inquiry-based writing instruction is the "Engagement" phase which sets out to arouse students' interest and share their prior experience. This initiationphase includes activating students' prior knowledge or probing students' pre-conceptions. The teacher facilitates the learning process in ways that enable students brainstorm possible questions, ideas and issues, to keep asking themselves, with each other, and with the teacher. The role of questioning is to arouse students' interest and encourage responses which reveal what students know or think about their writing issue (Warner \& Myers, 2014; Llewellyn, 2002; Owen, 2006; Marshall, 2013). Students 
visualize the whole inquiry process; determine topic areas for inquiry; discover possible sources of information; identify audience and writing format; assess and reflect on their engagement. In the process of inquiry-based writing instruction, at the engagement step, students get engaged in prewriting tasks using topic discovery Writing Process Sheets (WPS) which help them to activate their prior knowledge, and open up questions for writing topic discovery (Edward, 1983). In other terms, students initiate the learning process through generating ideas, and narrowing and clarifying writing topics using WPS that guide to discover, choose, and clarify a topic.

In exploration, students think about the information they have and the information they need, and actively search for information from different sources related to their writing topic. They manipulate materials, make interviews and observations, etc.; gather evidence, and discuss with colleagues. Students gather information on their academic writing topics from various sources with the help of WPS which guide them to discover and incorporate personal, social, and library sources (Edward, 1983). The teacher provides scaffolding to students by observing, questioning, and guiding. The students, then, think about the relevance of the information, evaluate it, and select the relevant information gathered on their writing topic.

In the explanation phase, students are provided opportunities to write their understanding, process skills, or behaviors. They write out their discovered concepts gained from the exploration using their own words. In their writing, students interpret and analyze data, provide evidence, communicate ideas, and justify conclusions. In other words, students organize the information gathered and produce their written texts considering their audiences. They thoroughly write drafts by evaluating, selecting, combining, and synthesizing the collected data. The inquirers compare, contrast, organize and sort, make connections between ideas, and draw inferences from their findings (Alberta Learning, 2004; Wale \& Bishaw, 2020). They revise and edit their written product to make their creation clear, concise, consistent and appropriate for the audience. Students revise their drafts for unity, coherence, and completeness, and proofread for mechanical problems (Edward, 1983). In doing so, students work with peers, teachers, and experts to develop their written text with feedback. The teacher provides feedback about the strengths and weaknesses of their draft; comment on what things would further develop the text and why (Alberta Learning, 2004). The teacher introduces relevant concepts, principles, and theories to help students develop deeper understanding (Llewellyn, 2002; Dawit, 2013; Warner \& Myers, 2014). Then by incorporating the feedback gained from others, students complete their final written essay.

In the Extension stage, students are provided opportunities to elaborate their thinking, transfer learning to their own real world situations beyond the school settings (Marshall, 2013; Alberta Learning, 2004). The extension phase helps students to set their conceptual understanding and develop a more permanent mental representation. Students; thus, identify alternative explanations; create connections between new concepts, principles, and theories to the real-world experiences, and apply them into new situations. The teacher facilitates the extension process while students extend their learning into real world situations. The application of this new knowledge provides an opportunity for students to move beyond memorization to deeper understanding of what they have learned, and become lifelong learners. The assessment in the extension phase is both summative and formative because students are required to assess the 
whole process of the inquiry learning, and at the same time they need to think more deeply about their academic writing and address weaknesses seen in the application of the new knowledge into the real life situation. In this extended stage; therefore, students produce sound academic texts on their own real life situations like what researchers and/or professional writers produce academic texts.

\section{The need for inquiry-based writing instruction}

The need for inquiry-based writing instruction is to fill the gaps of the existing learning methods. Various studies in English language instruction have revealed that most students are less effective in their English language academic achievement in general and academic writing skills in particular (Mohamed, 2015; Harris, 2015; Abdullah, 2014; Muhaimeed, 2013; Mesfin, 2013; Dawit, 2013; Bekele, 2011; Hamid, 2011, \& Hamid, 2010). Writing is a demanding task that challenges students to set goals, generate and organize ideas, and produce texts with appropriate language considering their readers (MacArthur, Philippakos, \& Graham, 2016). Hamid (2011) \& (Hamid, 2010) also found that planning, organizing, revising, and editing were the main problems of students who participated in the studies. Students faced difficulties in writing introduction, thesis statement, topic sentence, conclusion, and encountered cohesion and coherence problems. Likewise, Mohamed (2015) found that students have various problems including usage and mechanical mistakes, like spelling, punctuation and capitalization, and lack of several writing development skills.

According to Heather (2015) \& Birhan (2018), students' common pitfall in writing academic texts is the attempt to write a thesis statement before searching for information. At times, students become unable to present solid arguments due to lack of sufficient evidence for the proponent and opponent arguments. When students attempt to begin by writing a claim rather than gathering data as a part of an inquiry process, they often use claims that are based on hunches. This in turn creates problems for students as they attempt to substantiate their claims with no adequate evidence. Students also face challenges in identifying claim and evidence. While a claim is an arguable statement, evidence is the information that supports the claim. However, when students work through the inquiry process, they primarily identify what they know and what they want to know on their writing topic. Singman (2017) states that though the recent view of language learning has focused on how student-centered approaches can be applied in foreign language classes, the knowledge base for inquiry-based writing instruction is not firmly established in academic writing settings.

It has been noted by earlier scholars that conventional teaching methods are still in use though teachers are expected to use active learning methods (Daniel, 2004, and Dawit \& Yalew, 2008). The lecture method which is considered as the conventional method of teaching is used in colleges that teachers usually focus on giving lectures, and students depend primarily on lecture where discovery or inquiry is not that much encouraged. The product approach to teaching writing, specifically did not mostly encourage students to observe their environment critically, inquire or question things, investigate problems, and create new knowledge (Ferris \& Hedgcock, 2013; Graham, MacArthur; Fitzgerald, 2013 \& Yen, 2014). 
Nevertheless, it does not mean that the conventional method of teaching writing skills is not totally irrelevant because it has significant features which are helpful to develop writing skills. Atkinson (2003) and Sarala et al. (2014) stated that the product approach which is the conventional method encourages students to produce an end product which is likened to a model essay. The main aim of the approach is to provide linguistic knowledge to the students. The students are expected to have knowledge about language in general and producing texts in particular. As a result, students merely imitate sentences to get familiarity with the content. The teacher's feedback is also based on the grammatical and lexical errors. Thus, the students use model texts as the basis for their own writing. Using model texts give students confidence, and guarantee them to produce texts with fewer grammatical mistakes. The product approach is essential to get students focus on using specific piece of grammar in their writing. Therefore, the approach is useful when form is important in writing classes.

As it is stated above, however, the approach does not fully enable students to write texts independently because has little emphasis for creativity and personalization. It is also too prescriptive and lacks practical application. The process skills of writing, such as planning a text are less emphasized in the product approach. The writing tasks become decontextualized where the contexts and audience are often neglected (Sarala et al., 2014). Thus, the inquiry-based writing instruction is essential to fill the gaps of the conventional method. This points to the need to promote inquiry-based writing instruction which is based on a discovery approach that involve students in seeking, collecting, analyzing, synthesizing and evaluating information based on students' interest.

However, the inquiry-based writing instruction also has its own limitations though it makes students active, problem solver, autonomous, and lifelong learners. In theory, inquiry-based writing instruction maximizes engagement and gives students a chance to extract meaning and purpose from their education. However, it does not always stand the test of real-world application due to poorer standardized testing performance, student embarrassment, teacher unpreparedness, pursuit of greater engagement, and time (Awada et al., 2019; Demircioglu \& Ucar, 2015 \& Ulfah, 2012). When too much time is dedicated to student inquiries, there is often the risk that core writing topics could be left out. As a result, it hurts standardized testing performance in schools where standardized exams play a key role. In inquiry-based learning, students are required to be active participants. However, there is a risk of embarrassing students who may not be quick thinkers to process issues. Besides, for unprepared teachers, inquirybased learning is too haphazard. It prevents them from being able to prepare properly, which hurts their ability to engage students on a meaningful level.

Inquiry-based learning maximizes student engagement in ways that the conventional method do not. However, motivating all of the students in each writing lesson is often difficult since some students are naturally smarter than others. Ulfah (2012) stated that inquiry-based learning is inappropriate for unmotivated students. When the students are familiar with conventional way, they tend to write texts in the way they experienced in the conventional method of learning rather than the inquiry techniques. Finally, using inquiry-based writing instruction needs a longer time especially to discover writing topics, collect and synthesize data, and produce drafts. As a result, it is not easy to use this method in a limited time.

In sum, the literature shows that though both the conventional and the inquiry-based writing instructions have their own pros and cons, the pros of the inquiry-based 
learning outweigh its cons compared to the conventional approach. The inquiry-based writing instruction which is a discovery approach enables students produce their own academic texts independently, and makes them lifelong learners though it is not easy to implement. Nevertheless, the conventional approach to teaching writing skills is most likely unable to improve students' academic writing skills.

Studies revealed that students with the conventional approach faced difficulties in writing due to several factors including poor writing instruction, and inadequate writing practice. Several researchers investigating academic writing (e.g. Harris, 2015; Mesfin, 2013; Dawit, 2013; Bekele, 2011; Alamirew, 2005; Wale \& Bishaw, 2020; Birhan, 2018; Alemu, 2004, \& Italo, 1999) found that college level students' scores in writing tests were very low, and students were not able to meet expectations in writing tasks because of different reasons including poor writing instruction. Harris (2015) revealed that there were English language proficiency problems in students ranging from their ability of English language to their view of the language. In support of this claim, Dawit (2013) discovered that university students' level of English is plummeting very dramatically.

More specifically, Bekele (2011, p.16) stated:

Most university writing teachers mainly give notes, and sometimes models, and ask students to read the notes and produce a written text in line with the notes or the models given. They do not seem to be familiar with emerging techniques and approaches that could make students more active, responsible, confident, and eventually successful.

The current researchers' teaching experience also confirmed that many students have writing pitfalls in writing thesis statements, providing evidence, and identifying claims and evidence. They were also in difficulty to produce effective written texts that fulfill adequate content, organization, language usage or accuracy, vocabulary or diction, and mechanics. Moreover, the students were not adequately improving their academic writing skills using the conventional method of learning. This is because the students mostly did not engage to discover their own writing topics, search for information, evaluate the collected information, write up their texts based on the information they gathered, discuss with colleagues and experts, and produce their final text considering the given comments.

Thus, the literature and the researchers' teaching experience show that the existing teaching writing methods do not seem to be able to address the challenges of academic writing tasks that many students appear to face. Consequently, it is needed to consider discovery learning methods (such as inquiry-based writing instruction) that focused on learning by doing. This is reminiscent of the study of Alberta Learning's (2004) claim that inquiry-based writing instruction is indispensable to develop students' academic writing skills because the method focuses on the process of knowledge discovery that involves students in seeking, collecting, analyzing, synthesizing, and evaluating information; creating ideas, and solving problems through communication, collaboration, deep thinking, and learner autonomy, and ultimately helps them improve academic writing skills.

Even though there have been previous studies such as Boudreau (2017), Lee (2014), Ulfah (2012), Godbee (2016), Escalante (2013) and Ismail and Elias (2006) that 
conducted on the use of inquiry-based learning, there is still limited research regarding the effects of inquiry-based writing instruction on students' academic writing. Particularly, in the study area, inquiry-based writing instruction seems to have been a missing feature of English language writing. Therefore, in order to fill this research gap, the present study was conducted to investigate the effects of using inquiry-based writing instruction on students' academic writing skills.

\section{Research question}

The study was conducted to answer the following research question: What are the effects of using inquiry-based writing instruction on students' academic writing skills?

\section{Materials and methods}

\section{Research design}

The research design of the study was quasi-experimental that employed a pretestposttest two groups design. For the purpose of this study, two sections of Pharmacy students who enrolled for academic writing skills course were randomly assigned as experimental and control group. Both groups were given pretest and posttest before and after the intervention, inquiry-based writing instruction. The experimental group received the inquiry-based writing instruction; whereas, the control group learned through the conventional method.

\section{Participants of the study}

The participants of the study were first-year undergraduate Pharmacy students who were registered for the course Academic Writing Skills. There were two sections of first-year Pharmacy department students in the university. The researchers selected both sections of students using comprehensive sampling method, and randomly assigned them into experimental and control groups. While the experimental group has 32 students, the control group has 30 students.

\section{Instruments}

In order to gather data on the effects of using inquiry-based writing instruction on Pharmacy students' academic writing skills, test, focus group discussion, and students' reflective journal were used. The test has comprised both pretest and posttest, and was used to obtain data on the students' academic writing performance before and after the intervention. An essay writing pretest was given to both experimental and control groups to understand the students' existing academic writing skills before the intervention. In the same manner, other similar, but not the same essay writing posttest was also given to both groups after the intervention to determine whether the intervention made differences on students' academic writing skills. To put it in other words, the pre-test and post-test used in this study were similar rather than identical. This was done to reduce the repetition effect between pre-test and post-test on the students' test scores.

Accordingly, the pre-test was given before the intervention. Following the pre-test, the intervention was given for eight consecutive weeks. Then, the post-test which was similar with the pre-test was distributed to the students. Thus, since the pre-test and 
the post-test were distributed in different times (before and after the intervention), they were compared to made decisions about the development of students' academic writing performance. The students' essays were evaluated by two experienced English language university teachers using the British Council IELTS Writing Task descriptors. The task descriptors incorporated task achievement, coherence and cohesion, lexical resource, grammatical range and accuracy (British Council, 2018). Before the evaluation, training on the use of the rubric was given to the raters. Inter-rater reliability was calculated with Pearson's correlations, and it was found to be 0.8 which shows that it was reliable.

The focus group discussion was employed with eight students to collect qualitative data from the students' perspective on the development of their academic writing skills. The students were asked to forward their views on the relevance of inquiry-based writing instruction to develop their academic writing skills. In the same manner, the reflective journal was used to gather data on the effectiveness of inquiry-based writing instruction from the students' viewpoint. Accordingly, the students have reported their feelings on the effectiveness of the inquiry-based writing instruction and their improvements during the teaching learning process.

\section{Procedure}

Before the actual data collection, a learning material was prepared using the literature in accordance with inquiry-based writing instruction and academic writing. The learning material was developed in the way that enables students to make observations; pose questions; gather and synthesize data; propose answers, explain and predict; communicate findings through discussion and reflection; apply their findings to the real situation, and follow up new questions that arise in the process because these are the focuses of inquiry-based writing instruction. On the other hand, the material was also developed in the way that enables students to task achievement, coherence and cohesion, lexical resource, and grammatical range and accuracy. Thus, the instructional material was developed in accordance with the concepts of inquiry-based learning and academic writing skills.

Following the learning material preparation, essay writing pre-test was given to both the experimental and control group of students to understand their baseline academic writing skills. Then, the intervention was given for eight consecutive weeks. In the intervention, the experimental group received the inquiry-based writing instruction while the control group learned through the conventional learning method. In other terms, the experimental group students engaged in academic writing tasks including writing topic discovery, exploring data on their topics, discussion with peers and the teacher, write drafts based on the collected data, and finally produce essays considering their real life situation. On the other hand, the control group students informed about how to write academic texts to build their knowledge of writing. To do so, a teaching material which was designed in line with the conventional approach to teaching writing was given to the students to memorize the principles of academic writing, and to study the given model essays. In the teaching learning process, the teacher provided writing topics and model essays so that the students produce their own essays which were likened with the model texts. Accordingly, the students produced essays following the organization and sentence construction of the given sample essays. 
The experiment was conducted in a real course for language education. Thus, the control group students have given tutorial classes after the completion of the entire data collection process to resolve the educational unfairness between the control and experimental groups. The tutorial classes were designed based on the inquiry-based writing instruction principles to minimize the educational disadvantage of the control group students. However, this was done after the necessary data collection process and the intervention were finalized accordingly. Besides, The student-reflection journal was collected side by side while delivering the intervention.

Up on the completion of the intervention, both the experimental and control groups were given the essay writing post-test which was similar, but not the same, with the pre-test. The post-test was needed to determine whether the inquiry-based writing instruction could make improvements on the experimental group students' academic writing performance. Finally, the focus group discussion was conducted with the experimental group to gain information on the students' views about the effectiveness of using inquiry-based writing instruction in academic writing classes.

\section{Data analysis methods}

The data which were gathered through tests were analyzed using independent samples T-test in SPSS-version 26 software program. The independent samples T-test was used to examine whether there were differences between the experimental and control groups of students' academic writing scores. On the other hand, the qualitative data were analyzed thematically. In other terms, the focus group discussion transcripts and the students' reflective journal were closely examined to identify common themes or topics, ideas, and patterns of meaning. Accordingly, the collected data on the students' academic writing performance were examined and identified into common themes including writing task achievement, coherence and cohesion, lexical resource, and grammatical range and accuracy. Thus, the qualitative data were coherently presented based on these specific themes which are the features of academic writing performance.

\section{Results and discussion}

\section{Students' academic writing skills development}

In order to investigate the effects of using inquiry-based writing instruction on pharmacy students' academic writing skills, data were gathered through pretest and posttest before and after the intervention, respectively. Besides, qualitative data were also gathered through focus group discussion and students reflective journal. This section presents the results of the present study regarding students' academic writing performance using the inquiry-based writing instruction.

In order to assess the students' academic writing skills, descriptive statistics was run. Accordingly, Table 1 below shows that both the control and experimental groups had similar writing performance in the pre-test. The control group had a mean score 35.47; whereas, the experimental group had a 36.41 mean score. Even if it seemed that the students had some discrepancy, the difference they had was not statistically significant. This indicates that the students had similar writing performance before the intervention. 
Table 1 Descriptive Statistics of Control and Experimental Groups

\begin{tabular}{lllll}
\hline Participants & Test & N & Mean & Std. Deviation \\
\hline Control group & Pre-test & 30 & 35.47 & 1.655 \\
& Post-test & 30 & 37.20 & 2.188 \\
Experimental group & Pre-test & 32 & 36.41 & 1.757 \\
& Post-test & 32 & 46.31 & 2.292 \\
\hline
\end{tabular}

However, a significant difference was observed between the experimental and the control groups in the post-test writing scores due to the intervention. Based on the students' post-test scores, it was evident that the inquiry-based group showed more improvement in their academic writing than the control group. In the post-test, the control group had a mean score 37.20; whereas, the experimental group had a 46.31 mean score.

Therefore, these data revealed that although both groups of students improved their academic writing performance, the experimental group showed greater improvement. In the same manner, the students in the focus group discussion confirmed that they have developed their academic writing skills including content, coherence, organization, vocabulary, and grammar. Likewise, the students in their reflective journals reported that they were able to discover their own writing topic, construct clear thesis statement and topic sentence, write related supportive paragraphs, and make curious introduction and strong conclusion after using the inquiry-based writing instruction.

Besides, an independent $\mathrm{T}$ test was run to see the group statistics between the control and the experimental groups. As it can be seen in Table 2, the experimental group of students $(M=9.9062, S D=1.63351)$ scored higher test results than the control group of students $(M=1.7333, S D=1.68018)$.

Thus, the result implies that the inquiry-based group students had greater improvement on their academic writing skills compared to the conventional learning group students. In the same fashion, the data gained through focus group discussion revealed that the process of inquiry-based writing instruction enabled students to generate ideas, discover and clarify writing topics, explore information on their writing topics, explain their discoveries, and elaborate their thinking through transforming their understanding into their real world context. Similarly, the students in the reflective journals noted that they were asking questions on their writing topics, investigating data, connecting the topic to their experience, discussing with colleagues and experts, and reflecting on their learning process when they used the inquiry-based instruction. For instance, one of the students reported: "I have practically learned the writing skills beginning from discovering my writing topics to producing final drafts, rather than receiving writing rules from the teacher. In sum, most of the respondents (seven students among eight participants) assured that the inquiry-based writing tasks contributed to the enhancement of their academic writing skills.

Table 2 Group Statistics of Control and Experimental Groups

\begin{tabular}{llllll}
\hline & Groups & N & Mean & Std. Deviation & Std. Error Mean \\
\hline Total Results & Control Group & 30 & 1.7333 & 1.68018 & .30676 \\
& Experimental Group & 32 & 9.9062 & 1.63351 & .28877 \\
\hline
\end{tabular}


Finally, an independent samples $\mathrm{T}$ test was conducted to examine test result differences between the control group and experimental group students. As it is shown in Table 3, Levene's Test for Equality of Variances showed no violations, $P=.808$. The independent $\mathrm{t}$-test indicates that there was a statistically significant difference between the control group and the experimental group $(t=19.42, d f=60, P<.05)$. It reveals that the students who participated in the inquiry-based writing instruction outperformed in their academic writing skills.

In addition, data from the students' focus group discussion also revealed that using inquiry-based writing instruction helped students develop students' academic writing skills. The students' in their focus group discussion replied that they have developed their academic writing skills when they used the inquiry-based writing instruction in their academic writing lessons. The students reported "we have written various essays before using the inquiry-based writing instruction, but the essays were not that convincing. However, when we used the inquiry-based writing instruction, we became better academic writers due to the techniques we used in the learning process".

The students also viewed that inquiry-based writing instruction helped them to understand the ways how to discover writing topics, gather relevant data on their topic, evaluate the collected data, and write up essays as it provides them opportunities to incorporate feedback from colleagues and writing experts. Thus, the results gained from the focus group discussion revealed that using inquiry-based writing instruction in academic writing classes could help students develop their academic writing skills. This is because the method developed the students' performance in discovering writing topics, generating ideas, gathering and evaluating information from different sources, writing up drafts with evidences, discussing with colleague and experts, and thereby writing up effective essays.

Finally, the data gained through the students' reflective journal also indicated that the students' academic writing skills have been improved due to the inquiry-based writing instruction intervention. In the reflective journals, the students stated that the method of instruction was indispensable as it enabled them to be better academic writers because the method provides them responsibility to do writing tasks, and guides them how to produce academic texts using rich data.

One of the students mentioned: "This method of learning writing skills that we used is effective because it gave me the opportunity to discover my own questions through searching for information". The students viewed that their academic writing skills were developed due to the use of the inquiry-based writing instruction. The students replied that their competence to accomplish academic writing tasks has been improved because they were learning academic writing skills differently compared to their prior experience. Similarly, another student reported: "Before using the inquiry-based writing instruction, I tried to write essays simply with no techniques, but currently I used

Table 3 Independent Samples T test of Control and Experimental Groups

\begin{tabular}{|c|c|c|c|c|c|c|c|c|}
\hline & & $F$ & Sig. & $\mathbf{T}$ & Df & $\begin{array}{l}\text { Sig. }(2- \\
\text { tailed) }\end{array}$ & $\begin{array}{l}\text { Mean } \\
\text { Difference }\end{array}$ & $\begin{array}{l}\text { Std. Error } \\
\text { Difference }\end{array}$ \\
\hline \multirow[t]{2}{*}{$\begin{array}{l}\text { Total } \\
\text { Results }\end{array}$} & $\begin{array}{l}\text { Equal variances } \\
\text { assumed }\end{array}$ & .060 & .808 & 19.418 & 60 & .000 & 8.17292 & .42090 \\
\hline & $\begin{array}{l}\text { Equal variances not } \\
\text { assumed }\end{array}$ & & & 19.400 & 59.477 & .000 & 8.17292 & .42129 \\
\hline
\end{tabular}


various academic writing techniques. Thus, the inquiry-based writing techniques that I used in the teaching learning process were effective to develop my academic writing skills since I have got many things in the teaching learning process".

As the students reported in their reflective journals, the writing tasks given to them were relevant to them because the tasks were helpful to understand more about academic writing skills. The students confirmed that the writing activities given in the teaching learning process encouraged them because the activities lead them to discover ideas, gather and organize information, discuss with colleagues and experts, and produce effective essays.

In sum, the students in the focus group discussion and reflective journal revealed that they produced effective academic texts in terms of task response, coherence and cohesion, lexical resource, and grammatical range and accuracy when they used inquirybased learning in their writing classes. Besides, they also confirmed that they were able to develop good topic sentences, thesis statements, and supportive ideas when they develop essays through inquisition. Therefore, from the qualitative data it can be understood that the students have improved their writing performance through using the inquiry-based writing instruction because the method provided them an active role to discover their own writing topics, investigate necessary information, and produce sound texts based on appropriate feedback.

All in all, the results gained from the tests, focus group discussion, and students' reflective journal showed that the inquiry-based writing instruction developed the experimental group students' academic writing skills in terms of writing task achievement, coherence and cohesion, lexical resource, and grammatical range and accuracy. In other terms, the inquiry-based group students used good diction, sentences structure, and mechanics, and they were also able to develop good topic sentences, thesis statements, and supportive ideas when they wrote essays.

On the other hand, the control group students were clear about how to write academic texts, but not effective to produce sound texts in terms of writing task achievement, coherence and cohesion, lexical resource, and grammatical range and accuracy. This was because the students did not engage to discover their own writing topics and explore related data to their topics. They also received limited peer feedback and produced texts based on the given model texts, rather than collecting and synthesising information. The control group students, in their post-intervention essays, were unable to use good diction, sentences structure, and mechanics, and they were also incapable to develop good topic sentences, thesis statements, and supportive ideas.

These implies that the improvements in the experimental group were achieved as a result of using inquiry-based writing instruction that focused on engagement (activating prior knowledge and writing topic discovery); exploration (gathering and evaluating information from personal, social, and library sources); explanation (writing drafts using the collected data, and producing final texts based on feedback and audiences interest); and Extension (discovering new writing topics outside the classroom, and producing texts or essays on the real life situations like what researchers and/or professional writers produce academic texts.

As part of the inquiry-based writing instruction, the students have continuously assessed their learning and reflected on it in the classroom. In the learning process, the teacher provided scaffolding by observing, questioning, and guiding. In addition, the 
teacher also introduced relevant concepts, principles, and theories to help students develop deeper understanding on their academic writing skills through inquiry. Hence, with the support of the teachers, the engagement, exploration, explanation, extension, assessment and reflection processes could help students improve their academic writing skills. Thus, this study revealed that inquiry-based writing instruction could be used to improve students' academic writing skills since using the method enables students to discover new ideas beyond the classroom, and makes them be active, problem solver, autonomous, and lifelong learners.

This research finding is in tandem with previous research assertion in that inquirybased writing instruction helped students to improve their academic writing performance (Boudreau, 2017; Lee, 2014; Ulfah, 2012; Godbee, 2016, \& Escalante, 2013). Particularly, Boudreau (2017) revealed that inquiry-based writing instruction positively affects students' English language learning because the process of inquiry and self-discovery are the central part of the educational endeavor. As a result, students need the inquiry strategies and heuristics which help them on how to write effective texts, and to grow as writers. Similarly, a study conducted to assess students' feedback on the effectiveness of inquiry-based learning in second language pedagogy showed that the method developed students' understanding of the course material (Lee, 2014).

The findings of this study clearly indicate that inquiry-based learning has developed EFL students' academic writing skills. This is because the method developed their performances to discover writing topics, generate ideas, gather and evaluate information from different sources, write up drafts with evidences, discuss with colleague and subject area experts, and produce effective academic texts. In line with this finding, an earlier action research conducted to improve students' ability in writing through inquirybased writing instruction revealed that inquiry-based writing instruction could improve students' writing ability (Ulfah, 2012). Inquiry-based writing instruction has positive effects on students' academic writing skills because the method focuses on 'learning writing by doing' with little explicit instruction contrary to lecturing students on how to write. The results also indicate that the students see themselves as academic writers with real audiences beyond the classroom, learn the processes of posing and responding to questions, and connect academic with everyday concerns (Godbee, 2016).

Inquiry-based writing instruction developed the students' performances to discover writing topics, generate ideas, gather and evaluate information from different sources, write up drafts with evidences, discuss with colleague and subject area experts, and produce sound academic texts. Escalante (2013) also found that inquiry-based learning has positive impacts on EFL students' linguistic skills in general and writing skills in particular. Students who used inquiry-based learning techniques in their language learning are better achievers because they have an active role in choosing their writing topics, and on developing the outcomes of their own investigations. The method enabled students to acquire vocabulary, explore grammatical structures, and engage in the negotiation of meaning. In contrast to the current findings, some researchers like Ulfah (2012) found that inquiry-based learning is inappropriate for unmotivated students, not easy to do in limited time, and difficult to implement if the students are familiar with conventional way. In sum, the present study revealed that using inquiry-based writing instruction in academic writing class as an indispensible tool for students to develop their academic writing skills. 


\section{Conclusion and implications}

This research sought to examine the effects of inquiry-based writing instruction on students' academic writing skill, and showed the following major results. First, the study indicates that using inquiry-based writing instruction in academic writing class developed students' academic writing skills because the method provides active roles to the students to discover their own writing topics, investigate necessary information, and produce sound texts based on appropriate feedback. Another major result also shows that the students, in the inquiry-based writing instruction, saw themselves as academic writers with real audiences beyond the classroom, learned the processes of posing and responding to questions, and connected their learning with everyday concerns. The result of this research also elucidates that when the experimental group students used inquiry-based writing instruction in their academic writing class, they produced effective academic essays that addressed adequate task achievement, coherence and cohesion, lexical resource, grammatical range and accuracy. In other words, the students used good diction, sentences structure, and mechanics, and they were also able to develop good topic sentences, thesis statements, and supportive ideas when they wrote essays. However, the control group students were less effective in producing effective essays that fulfill task achievement, coherence and cohesion, lexical resource, grammatical range and accuracy. Besides, the students' essays were also insufficient in terms of diction, sentences structure, and mechanics. Apart from these, the topic sentences, thesis statements, and supportive ideas incorporated in the post-intervention essays were vague and unrelated each other.

The writing improvements in the experimental group were due to the inquiry-based writing instruction intervention that engaged students in prewriting tasks through generating ideas; discovering writing topics; exploring information on their writing topics from various sources; explaining their discoveries or concepts gained from the exploration, and elaborating their thinking through transforming their understanding into their real world situation. Thus, when students come up through this distinct writing process in manipulating such tasks, their academic writing skills has been developed because this process helped them develop their ability to analyze, synthesize, and evaluate various arguments. Using inquiry-based writing instruction in academic writing class developed students' academic writing skills because the method enabled them to discover writing topics, generate ideas, gather and evaluate information, write up drafts with evidences, discuss with colleague and subject area experts, and produce sound essays.

Therefore, inquiry-based writing instruction is suggested as a means to improve students' academic writing skills because the method incorporates activities oriented learning, logical arguments, and collaboration. This implies the need to promote inquirybased writing instruction which is based on a discovery approach that involve students in seeking, collecting, analyzing, synthesizing and evaluating information based on student interest. This is because using inquiry-based writing instruction in writing classes promotes students' academic writing performance and makes students be active, problem solver, autonomous, and lifelong learners.

Consequently, teachers should use inquiry-based writing instruction in their academic writing classes to develop students' academic writing skills. Likewise, academic writing teaching material developers need to consider the inquiry-based writing 
instruction principles in developing academic writing teaching materials so that students' improve their academic writing skills. Besides, students should also use the inquiry-based writing learning to produce effective academic texts, and become lifelong learners.

Lastly, the number of participants and the time given to the intervention, in this study, were relatively small. However, it does not mean that the findings of the study are not representative since the selected participants have similarities with other students. In addition, it does not mean that the intervention is completely inadequate since the students practiced the inquiry-based writing instruction exhaustively. It is to mean that the findings of the study would have been more convincing if a greater number of participants had been included, and more time to the intervention had been used in the study. As a result, such future exploration would have contributed to the current study, and is certainly an area ripe for future research. Furthermore, future studies should be also conducted on the use of inquiry-based instruction on other English language skills to widen the use of inquiry-based instruction.

Acknowledgements

Not Applicable.

\section{Authors' contributions}

The authors of the research have conducted the study, collected data, and analyzed and interpreted the collected data, and revised the manuscript critically. The authors take public responsibility for the whole content. They are accountable for all aspects of the work, and confirmed that they read and approved the final manuscript.

\section{Funding}

The study did not receive any funding.

Competing interests

The authors declare that there is no conflict of interest.

Received: 11 August 2020 Accepted: 27 December 2020

Published online: 15 January 2021

\section{References}

Abdullah, T. (2014). Developing critical thinking skills through writing in an internet-based environment. Int J Human Soc Sci, 4(1).

Alamirew, G. (2005). A Study on the Perception of Writing, Writing Instruction, and Students' Writing Performance. (PhD dissertation). Addis Ababa University.

Alberta Learning (2004). Focus on inquiry: A teacher's guide to implementing inquiry-based learning. Edmonton. http://www. learning.gov.ab.ca/k_12/curriculum/bySubject/focusoninquiry.pdf.

Alemu, H. (2004). An Evaluative Study of ELT Practices in Secondary Schools in Ethiopia 1994-2004. (PhD Thesis). India: Central Institute of English and Foreign Languages.

Atkinson, D. (2003). L2 writing in the post-process era: Introduction. Journal of Second Language Writing, 12(1), 3-15.

Awada, G., Burston, J., \& Ghannage, R. (2019). Effect of student team achievement division through WebQuest on EFL students' argumentative writing skills and their instructors' perceptions. Computer Assisted Language Learning, $33(2), 1-26$.

Bekele, B. (2011). The relationships of self-esteem and gender to writing performance: AMU year / students in focus. (MA thesis). Addis Ababa University.

Birhan, A. T. (2018). Effects of Mastery Learning Instruction on Engineering Students' Writing Skills Development and Motivation. Journal of Lanquage and Education, 4(4), 20-30. https://doi.org/10.17323/2411-7390-2018-4-4-20-30.

Boudreau, N. (2017). A principled revolution in the teaching of writing. English J., 106(5), 70-75.

British Council. (2018). IELTS Task 2 Writing Band Descriptors: Public Version.

Daniel, D. (2004). Observations and reflections of the higher education teachers on the quality of teaching and Learning in higher education in Ethiopia. Ethiopian J Educ, 1(1), 63-81.

Dawit, A. (2013). Enhancing students' writing skills through the genre approach. Int J English Literature., 4(5), $242-248$.

Dawit, M., \& Yalew, E. (2008). The Role of Teachers in the teaching Learning Process and the Development of Education: Past, present, and future.

Demircioglu, T., \& Ucar, S. (2015). Investigating the effect of argument-driven inquiry in laboratory instruction. Educational Sciences: Theory \& Practice, 15(1).

Edward, H. (1983). Writing: Process and convention.

Escalante, P. (2013). Inquiry-based Learning in an English as a foreign language class: A proposal. J Modern Language., 19, 479-485.

Ferris, D., \& Hedgcock, J. (2013). Teaching L2 composition: Purpose, process, and practice. Mahwah, NJ: Routledge. New York: McGraw-Hill. 
Godbee, B. (2016). Why inquiry matters: An argument and model for inquiry-based writing courses. The Wisconsin English J, 58(2), 7-21.

Graham, S., MacArthur, C., \& Fitzgerald, J. (2013). Best practices in writing instruction. New York: Guilford Press.

Hamid, A. (2010). Students' problems with cohesion and coherence in EFL essay writing in Egypt: Different perspectives. Literacy Information Computer EduC J (LICEJ)., 1(4).

Hamid, M. (2011). The EFL Essay Writing Difficulties of Egyptian Student Teachers of English: Implications for Essay Writing Curriculum and Instruction. Doctoral thesis. Egypt: University of Exeter.

Hardin, C. (2009). Effectiveness and accountability of the inquiry-based methodology in middle school science. [Master's Thesis]. Dominican University of California.

Harris, D. (2015). The status, roles and challenges of teaching English language in Ethiopia context: The case of selected primary and secondary schools in Hawassa University Technology Village area. Int J Sociol Educ., 4(2), 182-196.

Heather, C. (2015). Teaching argument writing: An inquiry process. Making the Common Core Come Alive., 5(1), 1-6.

Ismail, N., \& And Elias, S. (2006). Inquiry-based Learning: A new approach to classroom Learning. English Language J., 2(1), 1324.

Italo, B. (1999). A Comparison of the Effectiveness of Teacher versus Peer Feedback on Addis Ababa University Students' Writing Revision. [PhD Thesis]. Addis Ababa University.

Lee, Y. (2014). Inquiry-based teaching in second and foreign language pedagogy. J Language Teach Res, 5(6), 1236-1244.

Llewellyn, D. (2002). Inquire within: Implementing inquiry-based science standards. Thousand Oaks: Corwin Press, Inc.

MacArthur, C., Philippakos, Z., \& Graham, S. (2016). A multi component measure of writing motivation with basic college writers. Learning Disability Quarterly., 39(1), 31-43.

Marshall, J. (2013). Succeeding with inquiry in science and math classrooms. In What Framework Supports Effective InquiryBased Practice? Alexandria: ASCD.

Mesfin, A. (2013). An Exploratory Study on the Implementation of the Process Approach to the Teaching/Learning of the Course Basic Writing Skills: The Case of Hawassa University. Doctoral thesis. Addis Ababa: Addis Ababa University.

Mohamed, I. (2015). University students' English writing problems: Diagnosis and remedy. Int J English Language Teaching. 3(3), 40-52.

Muhaimeed, S. (2013). Task-Based Language Teaching Vs. Traditional Way of English Language Teaching in Saudi Intermediate Schools: A Comparative Study. (doctoral dissertation). Kent State University.

Owen, N. (2006). The Effects of Inquiry-Based Teaching on Attitudes, Self-Efficacy, and Science Reasoning Abilities of Students in Introductory Biology Courses at a Rural, Open-Enrollment Community College. (doctoral dissertation). Oklahoma State University.

Qing, L., \& Jin, S. (2007). An analysis of language teaching approaches and methods: Effectiveness and weakness. US-China Educ Rev, 4(1), 69-71.

Richards, J., \& Rodgers, T. (2001). Approaches and methods in language teaching. Cambridge: Cambridge University Press.

Sandoval, W. (2005). Understanding students' practical epistemologies and their influence on learning through inquiry. Sci Educ, 89(4), 634-656.

Sarala, T., Abdul, R., \& Fauziah, I. (2014). Comparative Analysis of Process Versus Product Approach of Teaching Writing in Malaysian Schools: Review of Literature. Middle East Journal of Scientific Research, 22(6), 789-795.

Singman, C. (2017). Towards an inquiry-based language Learning: Can a wiki help? International Journal of Research in English Education.

Ulfah, Y. (2012). Improving students' ability in writing through inquiry-based Learning. Action Research.

Wale, B.D., Bishaw, K.S. (2020). Effects of using inquiry-based learning on EFL students' critical thinking skills. Asian J Second Foreign Lang Educ, 5, 9. https://doi.org/10.1186/s40862-020-00090-2

Warner, A., \& Myers, B. (2014). Implementing inquiry-based teaching methods. University of Florida, IFAS Extension. https://edis. ifas.ufl.edu.

Yen, P. (2014). The impact of PPP and TBLT on Vietnamese students' writing performance and self-regulation. Doctoral Thesis. KU Leuven University.

\section{Publisher's Note}

Springer Nature remains neutral with regard to jurisdictional claims in published maps and institutional affiliations.

\section{Submit your manuscript to a SpringerOpen ${ }^{\circ}$ journal and benefit from:}

- Convenient online submission

- Rigorous peer review

- Open access: articles freely available online

- High visibility within the field

- Retaining the copyright to your article

Submit your next manuscript at $\boldsymbol{\nabla}$ springeropen.com 